\title{
DIESEL-ETHANOL TRUCK ENGINE FOR BRAZILIAN ETHANOL PLANTS: STRATEGY FOR ECONOMIC GAIN AND CLIMATE CHANGE MITIGATION
}

\section{ETANOL PARA CAMINHÕES DE USINAS DE ETANOL NO BRAZIL: ESTRATÉGIA PARA GANHO ECONÔMICO E MITIGAÇÃO DAS MUDANÇAS CLIMÁTICAS}

\author{
Mario A. Massagardi ${ }^{1}$; Patrícia Bilotta ${ }^{2}$ \\ ${ }^{1}$ Robert Bosch Latin-America Diesel-Systems Business Unit \\ mario.massagardi@br.bosch.com \\ ${ }^{2}$ Positivo University \\ pb.bilotta@gmail.com
}

\begin{abstract}
Dual-fuel diesel engine with ethanol injection is one of the promising technologies to allow ethanol use in commercial vehicles. Its main benefit is the possibility to calibrate the engine with similar combustion efficiency as diesel, but its challenge is to achieve higher substitution rates of diesel by ethanol. To check these limits, in this paper one engine prototype was built, calibrated and installed in a truck, to be used in duty cycle of the Brazilian ethanol industry (36 trips with total load of 63 ton and 28 trips with total load of 25 ton). In the tests it was evaluated: a) the performance of the diesel-ethanol engine in real conditions, $b$ ) the economic feasibility related to the ethanol costs, and c) the $\mathrm{CO}_{2}$ emission reduction via fuel switch (fossil by renewable fuel) from the United Nations Framework Convention on Climate Change methodology. As result of the tests, it was achieved slightly better fuel consumption in the diesel-ethanol mode, with an average substitution rate of $38 \%$. In addition, this result conducts to a positive cash flow of $8 \%$, if the ethanol costs were a half of the diesel price (limit value). For higher ethanol prices, the economic feasibility is marginal or non-existing and. In this case, Clean Development Mechanism (CDM) project could be decisive to the implementation of this technology in large scale in the Brazilian ethanol industry. The project can be justified by the $29 \%$ of $\mathrm{CO}_{2}$ emissions reduction due to the dual-fuel engine in comparison to the diesel mode.
\end{abstract}

Keywords: dual-fuel engines; $\mathrm{CO}_{2}$ reduction; renewable fuel; combustion efficiency.

\section{Introduction}

According to the Intergovernmental Painel on Climate Change (IPCC), "mitigation is a human intervention to reduce the sources or enhance the sinks of greenhouse gases". In this way, 
mitigation strategies may include a wide range of actions, overall new technologies to reach processes with higher efficiency (agriculture, industry, transport, building, etc), less consumption of energy or its replacement for renewable energies, suitable regulations and policies to minimize the climate change risks, and the need of changes in the consumer behavior, towards to a low-carbon society (IPCC, 2014).

The Brazilian commitment of reducing 36.1 to $38.9 \%$ of its greenhouse gases (GHG) emission until 2020 was stated in the Copenhagen agreement, in 2009. In the same year it was created the National Policy on Climate Change (BRASIL, 2009) and the National Plan on Climate Change (BRASIL, 2010) that define strategies to meet the Brazilian aim established in the international agreement. One of the directives of the Plan is to enlarge the use of renewable energy in substitution to fossil fuel, as diesel (BRASIL, 2010).

For industries, there are several possible motivations to partial or total replacement of fossil diesel by bio-fuel on their processes. It includes associating a "greener image" to the company, by the reduction of production $\mathrm{CO}_{2}$ footprint, reducing operational costs if bio-fuels are available at affordable prices, and compliance government regulations (Goldemberg et al., 2008). For the Brazilian ethanol production industries all of these motivations are valid as strategy of reducing the consumption of diesel fuel (Köhler et al., 2014), however, the solution needs to keep operational reliability and economic feasibility (Whanfried, 2011).

The ethanol industries demand great amount of fossil fuel to produce ethanol, in a ratio of 9.4, due to the consumption of diesel by the engine trucks during the transportation of the sugarcane to the processing plant. It means that about $115 \mathrm{~kg}$ of diesel fuel is required during the agricultural and industrial process to produce 1 ton of bio-ethanol. In this way, the set target is to reduce the diesel fuel consumption to a minimum value (Macedo et al., 2008).

Alternative power trains that operate with ethanol are one of the possible solutions on dualfuel truck engine. The diesel-ethanol technology is an option that provides several interesting customer values, like superior fuel efficiency and the capability to operate the tractors and trucks in the same duty cycle as diesel mode (Salles et al., 2009; Rezende et al., 2011; Dattatray and Satishchandra, 2011; Britto Jr. and Martins, 2014).

Aiming to prove the potential customer benefits and environmental gains of the dual-fuel engine to the ethanol industry, in this research one truck prototype was built and put in test under controlled field conditions. The purpose of this paper was to collect data from the prototype and to calculate the impact of the dual-fuel technology in the heavy transportation trucks in service on the surroundings of the Brazilian ethanol plants, considering: a) the performance of the dual-fuel engine in real conditions, b) the economic feasibility related to the fuel costs, and c) the $\mathrm{CO}_{2}$ emission 
reduction via fuel switch (diesel by renewable fuel). Based on these results, the authors will also present discussions related to the technology (applicability) and will suggest recommendations.

\subsection{Dual-fuel engine for ethanol use}

Ethanol can be used as a fuel in both spark-ignition and compression-ignition engines. Its largest application is currently in passenger cars equipped with spark-ignition engines. The fuel can vary from E100 (hydrated ethanol) till gasoline ethanol blends. Aiming a suitable engine for commercial vehicle and agricultural equipment applications, there are several techniques tested to use ethanol in compression-ignition engines. Ethanol blended to diesel in the fuel tank had many application constraints, like the need of using a co-solvent to allow a stable ethanol-diesel solution, the unsolved compromise among thermal efficiency and emissions, mainly nitrogen-oxides, and the negative impact on fuel costs due to the use of additives (Dattatray and Satishchandra, 2011; Boretti, 2012).

Another technologic pathway uses pure ethanol with a small amount of additives in compression-ignition engine, direct injection. Besides the public use of this technology in some European countries, this solution has severe technical constraints related to the uncommon solutions required to modify the engine for ethanol use. In this case, ethanol requires chemical additives to improve its detonation characteristics, but same additives are forbidden substance for civil use in many countries, highly explosive and harmful to human health. Non-dangerous alternatives have been developed, but their use requires engine design changes to achieve extremely high engine compression rate, resulting in a questionable solution, from the durability, reliability and fuel efficiency view-points (Moreira et al., 2008).

The third possible alternative is the dual-fuel engine. By definition, dual-fuels are compression-ignition engines those use two fuels simultaneously, in the same cycle (Britto Jr. and Martins, 2014). The main fuel is an alternative one, like Natural Gas or Ethanol, and the second one is diesel fuel, injected in small amount to start the ignition process. In dual-fuel vehicles, the two fuels are stored in separate tanks and their injections are managed by two separate electronic systems (Macedo et al., 2008; Moreira et al., 2008). The system is electronically integrated to allow two possible engine work modes: a) using $100 \%$ of diesel as fuel, b) replacing a significant amount of diesel by ethanol. From one side, the positive results in fuel consumption, emissions and combustion noise (Salles et al., 2009; Rezende et al., 2011), at the other hand, the absence of technical constraints for series production makes this solution to be recognized as one of the best currently engine available (Boretti, 2012). The benefits of this technique will be further demonstrated. 
The future development of the dual-fuel engines is the upgrade to ethanol direct injection, instead of injecting in the air-intake. The effective use will depend on designing specific engine configuration and direct injection fuel system components resistant to operate with ethanol. A study carried out by Boretti (2012) shows that increasing diesel substitution rate and maintaining diesel combustion a strong $\mathrm{CO}_{2}$ reduction is observed. On the other hand, Gargiulo et al. (2015) recently presented a study about carbonaceous particles on soot emissions from a diesel-ethanol engine with a prototype single cylinder research engine, and they concluded that higher the ethanol percentage in the mixture, higher the soot emission.

Rezende et al. (2011) report a study with one engine that was upgraded to dual-fuel technology, receiving components of a fuel injection system designed for ethanol direct injection. The engine management was done with two electronic control units, one of them loaded with experimental software capable to run dual-fuel functions. This engine was calibrated, assembled in an Iveco Tracker prototype, and put experimentally in service in an ethanol plant in Sao Paulo State, Brazil, working in severe conditions, transporting vinasse out of the plant till its deposit areas, during production season 2011/2012. The fuel consumption data of this prototype was collected in standardized way, allowing analysis of fuel substitution ratio and fuel efficiency comparison of the vehicle with diesel as fuel, and in diesel-ethanol mode (Rezende et al., 2011).

\section{Materials and methods}

Four steps were considered to provide evidences about the benefits of the diesel-ethanol fuel on $\mathrm{CO} 2$ emission reduction and economic feasibility:

a) To analyze the results of the engine calibration tests to assure that functional neutrality does exist in both diesel and diesel-ethanol operation modes, and the respective average fuel consumption data can be compared.

b) To evaluate the collected data of the vehicle tests, and determine the average fuel consumption for every operational mode, and the diesel substitution rate.

c) To analyze the economic evaluation of the project, considering the diesel and ethanol acquisition cost ratio at the Brazilian ethanol plants. A sensitiveness analysis will also be done, considering possible fuel price ratio variations in the future scenery.

d) To calculate the $\mathrm{CO}_{2}$ emission reduction with the diesel-ethanol engine technology, using the United Nations Framework Convention on Climate Change tool (UNFCCCa, 2008; $\mathrm{UNFCCCb}$; UNFCCCc). 


\subsection{Engine calibration test}

A calibration test with diesel-ethanol engine technology was carried out with a prototype truck in same speed and load conditions, torque, rated power curves and calibration maps of the original engine (only diesel). Under these conditions, it was possible to assure that the vehicle operational characteristics remain the same in both diesel or diesel-ethanol modes, and, as consequence, the fuel consumption data will be comparable. Table 1 shows the conditions of the engine calibration test to determine the maximum substitution rate in the diesel-ethanol mode.

Table 1. Engine conditions to determine the maximum substitution rate.

\begin{tabular}{|c|c|c|}
\hline Parameter to control & Expected results & Remarks \\
\hline Torque and rated power curves & Same in diesel and dual-fuel modes & Not to exceed original engine specification \\
\hline Combustion behavior & Absence of misfiring and knocking & $\begin{array}{l}\text { Avoid side-effects in performance and } \\
\text { durability }\end{array}$ \\
\hline Exhaust gas temperatures & $\begin{array}{l}\text { Not exceed in dual-fuel mode the } \\
\text { limits in diesel mode }\end{array}$ & Assure engine integrity and durability \\
\hline $\begin{array}{l}\text { Ethanol Injectors induction- } \\
\text { time limits }\end{array}$ & $\begin{array}{l}\text { Injector dimensioned to assure the } \\
\text { required injection quantity }\end{array}$ & Assure injection within duration limits \\
\hline Engine raw emission limits & $\begin{array}{l}\text { Not exceed in dual-fuel mode the } \\
\text { limits in diesel mode }\end{array}$ & Avoid negative impact on emissions \\
\hline
\end{tabular}

Table 2 shows the measured parameters and the variables involved in the test. The fuel consumption and the substitution rate of the truck were evaluated with diesel-ethanol and diesel engine in a road track of $16.4 \mathrm{~km}$. The testing path was defined with a total length of $32.8 \mathrm{~km}$ (round-trip in the road track) and a total of 64 trips.

Table 2. Parameters and variables involved in the truck test.

Variables considered

36 trips with total load of 63 ton

28 trips with total load of 25 ton

Standard trip sequence:

Trip 1: diesel mode (driver one); Trip 2: diesel mode (driver two); Trip 3: dual-fuel mode (driver one);

Trip 4: dual-fuel mode (driver two)

An initial fuel consumption measurement test was done under controlled conditions in two different ways: a) unloaded ( 25 tons), and b) loaded (63 tons). The results obtained in all 64 trips were analyzed as well as the average and standard deviation were calculated for the fuel consumption in diesel and diesel-ethanol modes, considering 25 ton and 63 ton.

The monitored values in this step were: travelled distance, travel time, vehicle load and fuel consumption for both diesel and diesel-ethanol mode. For ethanol, the equipment used was a fluid flow meter (model AIC 4008 VERITAS), with flow range 4 to $200 \mathrm{~L} \mathrm{~h}^{-1}$, and for diesel similar equipment was used (model AIC 6004 VERITAS), with flow range 1 to $120 \mathrm{~L} \mathrm{~h}^{-1}$. In addition, it 
was measured the nitrogen oxydes (NOx) and smoke emission for both diesel and diesel-ethanol modes.

\subsection{Economic feasibility analyze}

The effective fuel economy depends basically on two factors: 1) the substitution rate of diesel by ethanol and the cost relationship among diesel and ethanol. It is important to underline that the ethanol plants in Brazil purchase diesel fuel by commercial prices (including taxes) and have ethanol from their own production in a cost basis. Under this premise, the current cost is about 2:1 for diesel and ethanol, respectively. To determine the fuel economy sensitiveness on the fuel cost, the following formula was developed:

$\mathrm{FE}=[1-($ FCDDF. Pdiesel + FCEDF. Cethanol $) /($ FCDD . Pdiesel $)] \times 100$

FE is the fuel economy (\%)

FCDD is the total amount of diesel used in all tests in diesel-mode;

FCDDF is the amount of diesel and FCEDF is the amount of ethanol used in all tests in dual-fuel mode;

Pdiesel and Cethanol are respectively the diesel price and the ethanol cost at the plant.

\subsection{Well-to-Wheel (WTW) $\mathrm{CO}_{2}$ emissions inventory}

The emission inventory includes $\mathrm{CO}_{2}$ emissions in two conditions: a) the baseline emissions with diesel fuel, and b) the project with replacing part of the diesel fuel by ethanol. The emissions were calculated using Well-to-Wheel approach.

\subsubsection{Baseline emissions calculation according to CDM methodology}

Step 1: Calculation of $\mathrm{CO}_{2}$ emissions - Methodology tool (UNFCCCa, 2008)

$$
\text { PE FCj,y }=\sum F C i, j, y \times \text { COEFi,y }
$$

PE FCj,y is the total $\mathrm{CO} 2$ emissions from fossil fuel combustion in process $\mathrm{j}$, in year $\mathrm{y}(\mathrm{tCO} 2 / \mathrm{y})$;

$\sum \mathrm{FCi}, \mathrm{j}, \mathrm{y}$ is the quantity of fuel $\mathrm{i}$ in process $\mathrm{j}$, in mass or volume, in year $\mathrm{y}$;

$\mathrm{COEFi}$,y is the $\mathrm{CO} 2$ coefficient in $\mathrm{tCO} 2 /$ mass or volume of fuel $\mathrm{i}$, in year $\mathrm{y}$.

Step 2: Calculation of COEFi,y - Methodology tool (UNFCCCa, 2008)

$$
\mathrm{COEFi}, \mathrm{y}=\mathrm{NCVi}, \mathrm{y} \times \mathrm{EFCO} 2 \mathrm{i}, \mathrm{y}=3.021 \mathrm{tCO} 2 / \mathrm{m} 3
$$


$\mathrm{NCVi}$,y is the weighted average net calorific value of fuel " $\mathrm{i}$ " (for Diesel $=36.4 \times 10-3 \mathrm{TJ} / \mathrm{m} 3$ );

EFCO2 i,y is the Tank-to Wheel (TTW) weighted average CO2 emission factor per fuel, in year " $y$ ".

Diesel $=74 \mathrm{tCO} 2 / \mathrm{TJ}$ (Linke \& Alvarez, 2007) multiplied by factor 1.121, to convert it in Well-To-Wheel (WTW) emissions (UNFCCCa, 2008), resulting 83 tCO2 / TJ.

\subsubsection{Emissions calculation}

Once calculated the baseline emissions, the project emissions can be calculated simply multiplying that result by the previously calculated substitution rate, using the following formula:

PE FC j,y (project) = PE FC j,y (baseline) $x(1-S R) x(1+0.15 x S R)$

SR is the substitution rate of diesel by ethanol;

15\% Factor: non-neutral part of sugar cane ethanol $\mathrm{CO}_{2}$ emission, according to Moreira et al. (2008)

\subsection{Key assumptions}

Table 3 shows the ethanol production data for the Brazilian context and the data for the $\mathrm{CO}_{2}$ emission calculation (diesel and diesel-ethanol engine).

Table 3. Values considered for the calculation.

\begin{tabular}{ll}
\hline Actual data & \\
\hline Ethanol production harvest: & 28.2 million of $\mathrm{m}^{3}$ (PDE, 2011) \\
Diesel demand per ton of produced ethanol: & 0.115 ton $($ Macedo et al., 2008) \\
\hline Assumptions & \\
\hline Total diesel demand in ethanol industry: & 3.3 million of $\mathrm{m}^{3}$ \\
Percentage of diesel used in trucks: & $30 \%\left(1 \mathrm{million} \mathrm{of} \mathrm{m}^{3}\right)$ \\
\hline Diesel fuel characteristics & $0.85 \mathrm{~kg} \mathrm{~L}^{-1}$ \\
\hline Gravity density: & $0.848 \mathrm{tEP} / \mathrm{m}^{3} ; 1 \mathrm{tEP}=45.2 \times 10^{-3} \mathrm{TJ}$ \\
Energy content (Fconv): & \\
\hline Other data & $20.2 \mathrm{tC} / \mathrm{TJ}($ Carbon Emission factor for diesel) \\
\hline Carbon emission factor (Femiss): & 0.95 (for lower energy content) \\
\hline
\end{tabular}

\section{Results and discussion}

\subsection{Engine calibration}

Figure 1 shows the engine calibration results for diesel and diesel-ethanol modes, regarding the torque curve.

Figure 1 - Torque curve in diesel and diesel-ethanol modes. 


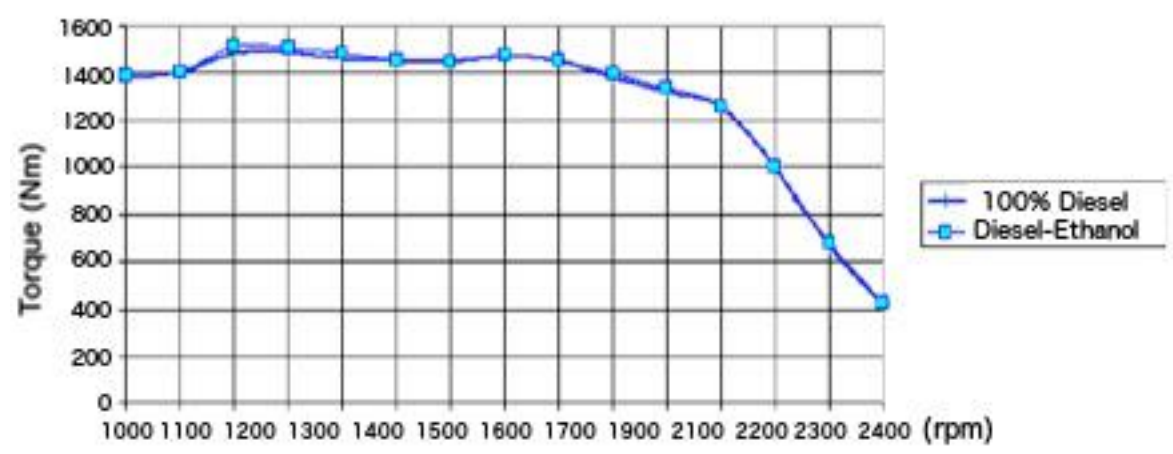

In the graphic presented by Figure 1, the continuous blue line indicates the original torquecurve of the engine, considering the diesel mode. On the other hand, the blue dots represent the torque-curve of the converted engine, after calibration, in dual fuel diesel-ethanol mode. In this case, the calibration goal was achieved, and the curve of the converted engine reproduces exactly the same values of the original engine (only diesel).

In addition, Figure 2 shows the results for 100\% load. For 100\% load, the achieved substitution rate was in the level of $30 \%$. In part-load, higher substitution rates were achieved.

Figure 2 - Diesel substitution rate by ethanol in $100 \%$ load.

\section{Engine speed $\left(10^{3} \mathrm{rpm}\right)$}

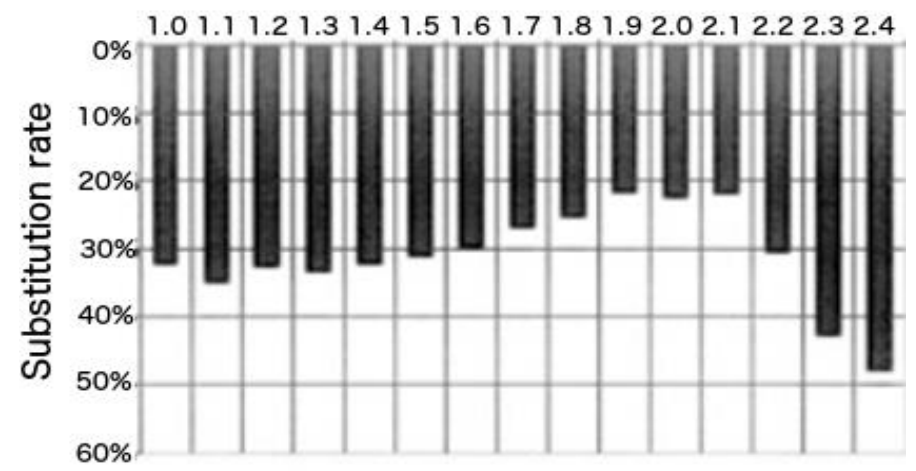

In terms of the emissions, it was measured NOx and smoke, aiming to assure that the new calibration was not providing worse emission levels than the original engine. Nitrogen oxydes and smoke were the measured exhaust-gases components, in steady state, for selected calibration points of the engine map. The smoke level was adopted as representing part of the particulate matter emissions. The values were noted in parts per million ( $\mathrm{ppm}$ ) of the exhaust-gases volume. Figure 3 shows the values obtained, which the continuous lines represent the values of the original diesel engine mode, and the doted ones are the values of the converted engine for dual-fuel mode.

Figure 3 - NOx and smoke measurements in the calibration tests. 

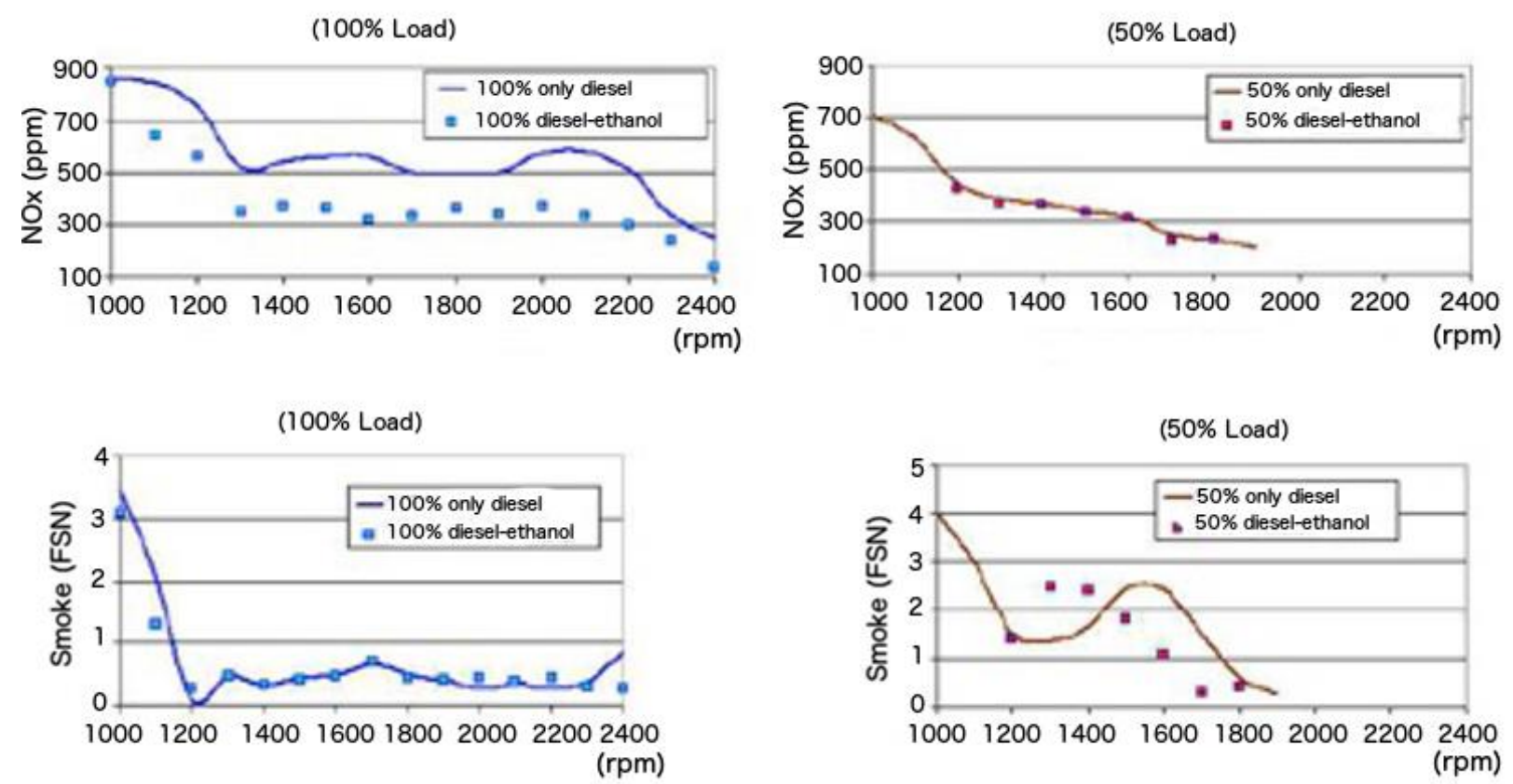

According to Figure 3, it is possible to note that both smoke and NOx emissions were kept close to the same level as the original diesel engine. Therefore, we can verify the dual-fuel engine had a good performance in the emission tests.

\subsection{Fuel consumption comparison and diesel substitution rate}

As result of the 64 round trips, the total amounts of diesel and ethanol used in the tests are summarized in Table 4. The diesel substitution rate is also calculated for each load condition.

Table 4. Accumulated fuel consumption and substitution rate.

\begin{tabular}{|c|c|c|c|c|c|c|}
\hline \multirow{2}{*}{$\begin{array}{c}\text { Vehicle } \\
\text { Weight } \\
\text { (ton) }\end{array}$} & \multirow[b]{2}{*}{$\begin{array}{l}\text { Diesel mode fuel } \\
\text { consumption (L) }\end{array}$} & \multicolumn{4}{|c|}{ Dual-fuel diesel-ethanol mode Fuel consumption $(\mathrm{L})$} & \multirow[b]{2}{*}{$\begin{array}{c}\text { Substitution } \\
\text { rate }(\%)\end{array}$} \\
\hline & & A - Diesel & B - Ethanol & $\begin{array}{c}\mathrm{C}-\text { Ethanol in } \\
\text { diesel equivalent } *\end{array}$ & $\mathbf{A}+\mathbf{C}$ & \\
\hline 63 & 569 & 355 & 333 & 212 & 567 & 37.4 \\
\hline 25 & 288 & 177 & 173 & 110 & 287 & 38.3 \\
\hline Total: & 857 & 532 & 506 & 322 & 854 & 37.6 \\
\hline
\end{tabular}

Statistical analysis of all data for each trip confirms 37.6\% substitution rate, 4.21 SD (AGRICEF, 2012).

${ }^{(*)}$ Ethanol consumption calculated in energy equivalent liters of diesel.

The comparison of the dual-fuel consumption of $854 \mathrm{~L}$ of diesel equivalent to the diesel mode fuel consumption of $857 \mathrm{~L}$ is very relevant to confirm that in both modes of operation the combustion efficiency and, as consequence, the fuel consumption remain approximately the same, with a very small advantage for dual-fuel. In fact, this behavior is also observed in the majority of the individual tests, that Dual-fuel mode was better in fuel efficiency in 17 out of 32 pair of tests.

The fuel consumption measurements show better substitution rate of diesel in the tests with 25 ton of total weight, when the expected results would be a better substitution with higher load. This could be a sign that the ethanol injectors were not appropriately dimensioned in this 
experience, reaching its injection quantity limits before full-load regime. If this assumption is correct, the calibration engineers had to compensate this problem by injecting a bigger amount of diesel if close to full-load, that limited the possibility of having a better substitution rate when operating with 63 tons.

The results and the description of the engine adaptation also show additional potential to improve de substitution rate to values in the range of $40 \%$ to $50 \%$. The more visible are: the correct dimensioning of ethanol injectors, the suitable installation of a throttle valve at air inlet to allow control of air-fuel ratio in the engine, the control of both fuels injection pressure and the installation of an electronic controlled in two stage turbo-charger. Higher substitution rates are possible but the direct injection technology is required for ethanol (Boretti, 2012).

\subsection{Fuel cost savings and sensitivity to diesel-ethanol price ratio}

The fuel cost saving was simulated for ethanol-diesel fuel cost relationship for $40 \%$ till $70 \%$. Figure 4 shows sensitiveness curve for the results.

Figure 4 - Fuel economy according to ethanol-diesel cost relationship.

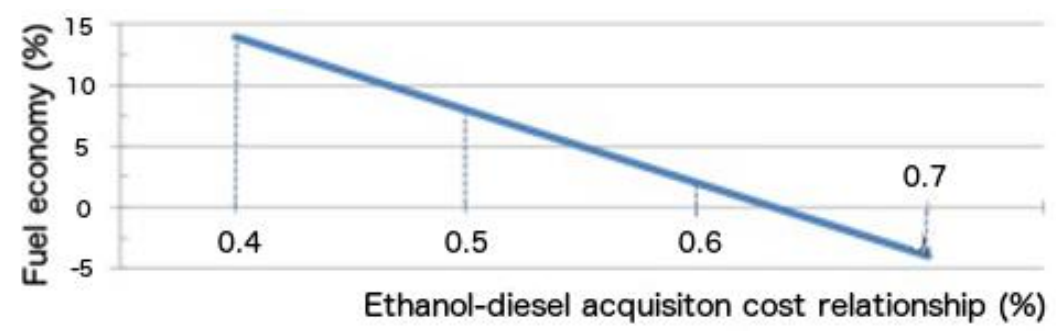

According to Figure 4, the cost relationship during the tests was 1:2 (ethanol cost was about $50 \%$ of diesel price) and the fuel cost saving was $8 \%$. The sensitiveness check, at the other hand, shows only $2 \%$ cost savings in case ethanol costs at the plant is $60 \%$ of diesel price and no savings for cost relationship bigger than $63 \%$.

Besides the $8 \%$ of the fuel cost savings in the condition of the dual-fuel diesel-ethanol plant, the sensitive analysis shows marginal economic feasibility with ethanol cost in the range of $60 \%$ of diesel price, and no feasibility above this value (Figure 4).

Considering that ethanol and diesel prices, and their relationship, they are hardly predictable in long-term, and considering the possible large-scale introduction of dual-fuel technology in ethanol industry truck fleet, the realistic analysis is that the project would have just limited economic attractiveness, not being possible to assure long-term economic return.

\section{4 $\mathrm{CO}_{2}$ emission reduction}


To calculate the impact of the dual-fuel engine on $\mathrm{CO}_{2}$ emissions, the selected method was based on Clean Development Mechanism (CDM) project methodology, recommended by United Nations Framework Convention on Climate Change - UNFCCC (UNFCCCa), that allows to calculate the $\mathrm{CO}_{2}$ emission reduction considering the baseline for diesel truck engine and the project status for the use of the technology under pre-defined premises, selected to be realistic, and considering the reality for the Brazilian ethanol industry (as showed in Table 3). The results obtained are given in Table 5.

Table $5-\mathrm{CO}_{2}$ emission results.

\begin{tabular}{ll}
\hline Status & $\mathrm{CO}_{2}$ emissions \\
\hline Baseline & 3.00 million $\mathrm{tCO}_{2}$ year $^{-1}$ \\
Project & 1.97 million $\mathrm{tCO}_{2}$ year $^{-1}$ \\
Emission reduction & 1.03 million $\mathrm{tCO}_{2}$ year \\
\hline
\end{tabular}

The calculation shows that the estimated truck fleet for the Brazilian ethanol industry emits 3.00 million $\mathrm{tCO}_{2}$ per year. The project status calculation reveals that the use of the dual-fuel technology would reduce this value to 1.97 million $\mathrm{tCO}_{2}$ per year. Therefore, the total reduced amount, under these premises, would be 1.03 million tCO2 per year, or $34 \%$ of baseline situation.

In the context of the global efforts to mitigate the climate change, and considering the GHG reduction Brazilian target, the use of dual-fuel engine in the ethanol industry truck fleet on largescale can bring a further environmental contribution, due to a large amount of $\mathrm{CO}_{2}$ emissions avoided, based on the fuel switch from fossil to renewable energy. In addition, values above $34 \%$ are expected to $\mathrm{CO}_{2}$ emissions avoided, with the possible technical improvement of the dieselethanol truck engine.

However, the environmental gains may be much more attractive than the economic return. In this case, the CDM tool (mechanism established by the Kyoto Protocol to stimulate emission reduction projects in developing countries) may be a way to make the dual-fuel engine implementation possible on large scale, besides economic risks.

Under categorization AMS-III $\mathrm{S}$ of the UNFCCC (fuel switch for less intensive $\mathrm{CO}_{2}$ emission fuel in transportation fleets), the CDM tool depends on the project boundaries (geographical area per number of vehicles, for example) to allow effective monitoring and precise quantifying of $\mathrm{CO}_{2}$ emission reduction. Thus, one ton of $\mathrm{CO}_{2}$ equivalent $\left(\mathrm{tCO}_{2 \mathrm{eq}}\right)$ avoided is equal to 1 Certified Emission Reduction (CER), or carbon credit, that can be negotiated in the carbon markets (UNFCCCb, 2014; UNFCCCc, 2015).

However, the low economic value negotiated currently for the CERs may be a limitation for the CDM projects. On the other hand, in December 2015, it will happen the 21 st Conference of the 
Parts to the United Nations, that will be in Paris, and it is been expected a new direction for the Kyoto agreement toward the mitigation the global climate change effect.

Finally, the measurement and optimization of exhaust gas emissions were out of the scope of this vehicle test, but it needs to be considered for series application projects. For this reason, the authors of this paper consider important to carry on studies about diesel-ethanol engines to measure exhaust gas emissions in full transient tests, following the specification of a valid Brazilian regulation (currently the Emission Standard is Proconve P7). For specific use of ethanol in dual-fuel engine, aldehyde emissions need to be evaluated and controlled as well.

\section{Conclusions}

Dual-fuel engines with ethanol intake injection are able to keep diesel efficiency in engine tests and in truck vehicle tests, allowing substitution in the range close to 38\%. Application of stateof-art technology can improve substitution rate above $40 \%$.

With $38 \%$ substitution rate, the economic feasibility of a large-scale dual-fuel engine project will be extremely dependent on ethanol costs and diesel prices, and on their relationship; however, positive economic results cannot be assured in long-term.

The use of dual-fuel, intake ethanol injection engines can drive to significant environmental gains in terms of $\mathrm{CO}_{2}$ emission reduction, by replacing $38 \%$ of fossil fuel (diesel) by renewable one (ethanol), and reducing the amount of fossil fuels used in ethanol production. In this test with Brazilian ethanol, a $\mathrm{CO}_{2}$ emission reduction of $34 \%$ was achieved. The further development of dual-fuel technology for ethanol use will allow direct ethanol injection in engine combustion chamber and it has the potential to significantly increase the diesel fuel substitution rate, as well as to reduce $\mathrm{CO}_{2}$ emissions, and therefore, to improve the economic and environmental attractiveness of this type of project for the ethanol industry.

\section{References}

BORETTI, A. Advantages of converting diesel engines to run as dual fuel ethanol-diesel. Applied Thermal Engineering. v. 47, p. 1-9, 2012. crossref

BRITTO Jr., R. F.; MARTINS, C. P. Experimental analysis of a diesel engine operating in diesel ethanol dual-fuel mode. Fuel. v. 134, p. 140-150, 2014. crossref

BRASIL. Lei n. 12.187, de 29 de dezembro de 2009. Institui a Política Nacional sobre Mudança do Clima - PNMC e dá outras providências. Diário Oficial [da] União, Presidência da República, Brasília, DF, 29 dez. 2009. Acess: <http://www.planalto.gov.br/ccivil_03/_ato2007-2010/2009/lei/112187.htm>

BRASIL. Decreto n. 7.390, de 9 de dezembro de 2010. Regulamenta os arts. 6, 11 e 12 da Lei no 12.187, de 29 de dezembro de 2009, que institui a Política Nacional sobre Mudanças do Clima - PNMC, e dá outras providências. Diário Oficial [da] União, Presidência da República, Brasília, DF, 09 dez. 2010. Acess:

<http://www.planalto.gov.br/ccivil_03/_Ato2007-2010/2010/Decreto/D7390.htm> 
DATTATRAY, B. H.; SATISHCHANDRA, V. J. Performance, emission and combustion characteristic of a multicylinder di diesel engine running on diesel-ethanol-biodiesel blends of high ethanol content. Applied Energy. v. 88 , p. 5042-5055, 2011. crossref

GARGIULO, V.; ALFÈ, M.; BLASIO, G. DI.; BEATRICE, C. Chemico-physical features of soot emissions from a dual-fuel ethanol-diesel system. Fuel, v. 150, p.154-161, 2015. crossref

GOLDEMBERG, J.; COELHO, S. T.; GUARDABASSI, P. The sustainability of ethanol production from surgarcane. Energy Policy. v. 36, p. 2086-2097, 2008. crossref

IPCC. Working Group III Contribution to the IPCC 5th Assessment Report - Changes to the underlying Scientific/Technical Assessment. Cambridge, Intergovernmental Panel on Climate Change, WMO/ UNEP, 2014. Acess: 〈https://www.ipcc.ch/pdf/assessment-report/ar5/wg3/ipcc_wg3 ar5 full.pdf>

KÖHLER, J.; WALZ, R., MARSCHEIDER-WEIDEMANN, F. Eco-Innovation in NICs: conditions for export success with an application to biofuels in transport. Journal of Environment \& Development. v. 23, p.133-159, 2014.

crossref

LINKE, R.; ALVAREZ, O. Jr. Metodologia simplificada de cálculo das emissões de gases do efeito estufa de frotas de veículos no Brasil. São Paulo Environmental Company - CETESB. São Paulo, 2007. Acess:

<http://www.ambiente.sp.gov.br/proclima/PDF/inventario_efeitoestufa.pdf>

MACEDO, I. C.; SEABRA, J. E. A.; SILVA, J. E. A. R. Greenhouse gases emissions in the production and use of ethanol from sugarcane in Brazil: the 2005/2006 averages and a prediction for 2020. Biomass and Bioenergy. v. 32, p. 582-595, 2008. cross ref

MOREIRA, J. R.; VELÁZQUEZ, S. M. S. G.; APOLINÁRIO, S. M.; MELO, E. H.; ELMADJIAN, P. H. Projeto best bioetanol para o transporte sustentável. Electrical Engineering and Energy Institute, National Biomass Reference Center (CENBIO). Technical Report, São Paulo, 2008. Acess:

<http://cenbio.iee.usp.br/download/publicacoes/bestagrener18jun2008.pdf>

PDE. Ministry of Mines and Energy. Brazilian Decennial Plan for Energy Expansion - 2020. p. 53, 2011. Acess: <http://www.epe.gov.br/PDEE/20120302_2.pdf>

REZENDE, H.; FURQUIM, R.; ODLEVAK, E.; ELIZARDO, C. R. E.; SALLES, E.; MOLGORI, S. Ethanol diesel truck engine. SAE International, SAE Technical Paper Series. p. 036-0319, 2011.

SALLES, E.; ZAMBOTTI, A.; GOUVÊA, A.; ASSIS, A. An experimental study of diesel-ethanol combustion controlled electronically. In. XVII INTERNATIONAL SYMPOSIUM OF AUTOMOTIVE ENGINEERING, 16, 2009, São Paulo. Anais... São Paulo: Brazilian Association of Automotive Engineering (AEA). Acess: 〈http://www.aea.org.br/aea2009/downloads/simea09/pap/PAP0041.pdf〉

UNFCCCa. United Nations - Tool to calculate project or leakage of $\mathrm{CO}_{2}$ emissions from fossil fuel combustion Methodological tool. CDM Executive Board, EB41 Report, Annex 11, 2008. Acess: <http://cdm.unfccc.int/EB/041/eb41_repan11.pdf>

UNFCCCb. United Nations - CDM Methodology Booklet, United Nations Framework Convention on Climate Change. Bonn/Germany: 6. ed, 2014. Acess:

<https://cdm.unfccc.int/methodologies/documentation/meth_booklet.pdf\#AMS_III_S >

UNFCCCc. United Nations - Small-scale methodology - Introduction of low-emission vehicles / technologies to commercial vehicle fleets. United Nations Framework Convention on Climate Change, 2015. Acess: <https://cdm.unfccc.int/filestorage/q/t/2O6QYCVZS5JB0IAPKFRW3D74H1X8MN.pdf/EB70_repan29_AMSIII.S ver04.0.pdf?t=M1J8bm56b3VufDATe66GuHfjC82CozvDbAQk >

WHANFRIED, C. Etanol em ciclo diesel. Technical presentation, Robert Bosch Ltda, Rio de Janeiro, 2011. Acess: <http://www.estacaomultimidia.com/fetranspor/fetransporseminario/palestras/Painel\%202/Mario\%20Angelo\%20Massa gardi/DG_RJ\%20(2).pptx> 
Dados dos autores:

\section{Mario A. Massagardi ${ }^{1}$ and Patrícia Bilotta ${ }^{2}$}

${ }^{1}$ Master's in Environmental Management. Robert Bosch Latin-America, Diesel-Systems Business Unit. Adress: 11,800 Juscelino K. de Oliveira Avenue, CEP 81460-900, Curitiba, Paraná, Brazil. Email:mario.massagardi@br.bosch.com

${ }^{2}$ Corresponding author. Ph.D. Professor. Climate Changes area. Master's and Doctorate Program in Environmental Management. Positivo University. Adress: 5,300 Prof. Pedro Viriato Parigot de Souza, CEP 81280-330, Curitiba, Paraná, Brazil. Email: pb.bilotta@ gmail.com

Submetido em: 07-05-2015

Aceito em: 14-09-2015 